\title{
Synergy of Family Business and Social Entrepreneurship: Problems of Law, Economics and Technology Development
}

\author{
Anatoly N. Levushkin ${ }^{1 *}$, Yana S. Grishina ${ }^{2}$, Olga G. Bartkova ${ }^{3}$, and Tatyana V. Savina ${ }^{4}$ \\ ${ }^{1}$ Kutafin Moscow State Law University (MSAL), Department of Business and Corporate Law, \\ Moscow, Russia \\ ${ }^{2}$ The Russian State University of Justice (RSUJ), Department of Civil Law, Moscow, Russia \\ ${ }^{3}$ Tver State University, Department of Civil Law, Tver, Russia \\ ${ }^{4}$ Ulyanovsk State University, Department of Civil and Business Law, Ulyanovsk, Russia
}

\begin{abstract}
During the economic instability, crisis processes in economic relations, and the growing prospects of a new "step" of the global economic crisis, theoretical and applied research in the field of legal support for strengthening and supporting economic development, small and medium-sized businesses, and digital technologies in the Russian Federation plays a great role.

The purpose of the study: A legal study of the current legislation in order to apply the concept of synergy of family business and social entrepreneurship for the effective implementation of economic processes and solving technological problems, identify the problems of family business development in the new economic realities and propose some ways to solve them at the legislative level.

The object of the study is a set of economic, entrepreneurial, civil-legal relations that arise in the implementation of family business and social entrepreneurship in modern economic realities based on new technologies. Methods: General scientific and private scientific methods of scientific cognition were used in the study: systematic, historical, logical, comparative-legal, formal-legal, and others.

Novelty: It is proved that social entrepreneurship and family business should be a system-forming link in economic relations, linking the state with small and medium-sized businesses. The introduction of such form of business (social and family entrepreneurship) should eliminate many economic problems and gaps in the legal regulation of issues that arise while conducting economic activities by family members. The necessity of separating social entrepreneurship and family business into a separate economic and legal category is justified, and the expediency of consolidating the concept of social entrepreneurship and family enterprise at the federal level is proved.
\end{abstract}

\footnotetext{
*Corresponding author: lewuskin@mail.ru
} 


\section{Introduction}

In recent years, the possibility of introducing and consolidating in Russian legislation the model of social entrepreneurship and family business as a sphere of economic activity, which is reflected in the real steps aimed at the formation and development of such a direction of business organization in Russia has been increasingly discussed. In many foreign economic legal systems, especially in countries with developed economies, social entrepreneurship and family business are common phenomena, approved and strongly supported by both the state and society. An obvious and long-overdue necessity is the need to modernize and adapt domestic legislation to the modern realities of economic relations and business. The article proves the necessity of legislative consolidation of the possibility of implementing the concept of social and family entrepreneurship in economic relations, the implementation of the idea of creating a family enterprise in order to effectively implement socio-economic tasks and technological processes on the territory of the Russian Federation.

The study of social entrepreneurship and family business, as objectively existing economic and legal phenomena, is at the intersection of many sciences: economic, legal, and social. Despite the fact that in most countries of the world, family business and entrepreneurship is a very common and popular economic and legal phenomenon, in Russia, family business is not implemented so frequently and for the most part remains incomprehensible to the average entrepreneur. Family business in Russia is a phenomenon that is not fully studied, but requires special doctrinal and practical attention. The study of social entrepreneurship and family business, as objectively existing economic and legal phenomena, is at the intersection of many sciences: economic, legal, and social. Despite the fact that in most countries of the world, family business and entrepreneurship is a very common and popular economic and legal phenomenon, in Russia, family business is not implemented so often and for the most part remains incomprehensible to the average entrepreneur. Family business in Russia seems to be a phenomenon that has not been fully studied, but requires special doctrinal and practical attention. All of the above mentioned issues are now becoming more important than ever and are of great interest among participants in economic activities and business processes. In this regard, it is worth fully agreeing with L. V. Maksimovich that there is a whole layer of relations at the intersection of commercial and family law, including in the field of family entrepreneurship, the legal regulation of which is difficult due to the lack of the necessary regulatory framework [1].

Legal regulation. "At the international legal level, there is a regulation of relations of a civil nature, business activities, relations with the participation of public institutions, state organs. Relations in the sphere of safeguarding and protecting the property rights of the Russian Federation are also widely applied at the international level, especially in time of the so-called sanctions of foreign states currently applied to the Russian Federation, which are mainly discriminatory against Russia [2]. As Russian President Vladimir Putin emphasized in 2019 at a meeting with the President of the Chamber of Commerce and Industry Sergey Katyrin, it is necessary to define a clear definition of "family business" so that family enterprises can freely receive state support [3]. The Ministry of Economic Development of the Russian Federation has already prepared a draft law for the introduction of the concept of "family enterprise" into the legislation, the corresponding document is published on the portal of normative legal acts, public discussions are currently held. As many experts note, the enactment of this law will create legal and organizational conditions for the active development of family business, social guarantees and regulated labor relations. However, in our opinion, the submitted draft law is related exclusively to the concept of a family enterprise for the purpose of obtaining state support, and does not 
solve a number of socio-economic problems that are beyond the obtaining appropriate benefits and subsidies from the state.

Today we can claim, that the socio-economic relations between family members are regulated not only by the norms of family law, but also by civil, business, corporate, and labor law, i.e. they have an intersectoral content. We believe that in the practical sphere, the processes of synergy between family business and social entrepreneurship are actively implemented, aimed at solving the problems of the development of law, economics and modern digital technologies. Such relations between family members, as subjects of economic activity, determines the emerging convergence of private and public legal regulation of this sphere. Thus, the prospects for the development of family business as an economic model of business organization in Russia directly depend on the need to introduce a well-developed legislative framework for the implementation of social entrepreneurship and family business on the basis of intersectoral legal regulation and synergy of economic, legal and technological phenomena. According to the opinion of Y. S. Grishina, the full implementation of social entrepreneurship in the legal field of Russia is possible through the enactment of a specialized federal law [4].

\section{Results}

It seems that a clear and detailed legislative regulation of social entrepreneurship and family business, based on the harmonization of legal regulation of private and public law relations, could solve a number of economic, technological and corporate problems. This conclusion is suggested by the analysis of the economic activities conducted by the spouses, including those involved in corporate relations. The business of the spouses as a complex economic category is a combination of property and some non-property elements of the realization of the rights of the spouses in the implementation of business activities carried out in various areas of economic activity, the income from the realisation is transferred to the joint property of the spouses.

It is determined that the rapid development and spread of technologies requires business changes in the services provided. There is a gradual digitalization of services, they are moving to the online sphere [5].

The expansion of opportunities for economic activity and business through the emergence of new areas of private capital investment, as well as government incentives and support for the development of small and medium-sized businesses, gradually lead to an increase in the activity of subjects in the field of family business and civil turnover to create and participate in the activities of legal entities. Taking into account the most common option of participation of spouses in the creation of a limited liability company by acquiring the status of a member of the company only by one of the spouses, over time, issues of organization of family matrimonial business, ownership and use of business assets of family members, division of family business, disposal of it, inheritance of the deceased spouse's share in the authorized fund of a business company, issues of registration and implementation of the rights of the surviving spouse become increasingly relevant. There is clearly an interdisciplinary and intersectoral approach to the regulation of such relations at the level of Russian legislation and economic regulators.

Public-private partnership allows the interaction of three entities in solving socially oriented economic problems - the state, which wants and strives to achieve certain socially significant goals; business, which has assumed a certain social responsibility; sociallyoriented entrepreneurs, business process entities. In other words, it can be argued that public-private partnership is a special case of socially-oriented behavior of economic entities. 
Separate conclusions are formulated regarding the definition of the legal nature of the business of the spouses as an object of law and the form of economic activity: a) the business of the spouses is capital (shares, shares, units), property complexes, enterprises owned or controlled by the spouses. This should include both small businesses and public companies based on private ownership; b) the business of spouses is a variety of forms of economic and entrepreneurial activities, the organization and functioning of business models of family technological entrepreneurship.

\section{Discussion}

In many developed foreign legal systems with a market economy, social entrepreneurship usually takes a leading place in the quantitative calculation of the totality of various types of business. At the same time, family entrepreneurship as a kind of social entrepreneurship is not the most popular form of doing business, but it has already developed in the modern realities of the Russian economic turnover [6]. Indeed, social entrepreneurship is certainly an important area for the development of business processes and legislation.

Social entrepreneurship, which has received scientific justification in Russia in the works of Professor A.V. Barkov, contributes to the formation of a stable and stable socially-oriented economic environment, and also lays the prerequisites for the formation of a competitive business environment on the world market. Leskova offers a very interesting judgment, according to it, «given the fact that the federal budget is exhausted and, as a result, state support, in Russia it is worth paying attention to other stimulating methods (methods, measures) the «emergence» of social entrepreneurs, the experience of legalizing a social enterprise in the United States using those structures and institutions that already exist in Russia and can become a kind of barrier to the admission of unscrupulous social entrepreneurs to the social services market» [7].

The expansion of business opportunities due to the emergence of new areas of private capital investment, as well as the stimulation and support of entrepreneurial activity of the population, gradually lead to an increase in entrepreneurial opportunities and the activation of the activities of business entities. The domestic economy is currently approaching a developed market system, in which new forms and types of entrepreneurial activity are becoming important. Grishin's doctrine rightly points out that social entrepreneurship has proven itself on the positive side in foreign legal systems while solving various social problems in society and the state. Consequently, as Article 7 of the Constitution of the Russian Federation proclaims Russia a social state, in order to guarantee a decent standard of living for Russian citizens, it is necessary to actively use various available anti-crisis mechanisms, including social entrepreneurship [8]. Indeed, it is necessary to pay attention to the fact that many problems of a socio-economic nature could be solved through this line of business activity.

It should be noted that among the main theories of family business in social and legal science, the system theory is distinguished (System Theory), in the context of it, the family and business are considered as two systems that have their own characteristics [9]. The entrepreneurial activity of spouses and other family members is characterized by the fact that it simultaneously belongs to the sphere of economic, civil, family legal relations and, in general, social legal relations. In the doctrine of business law, Professor Yu. G. Leskova justifiably defines that the legal status of the subjects of legal relations is determined not only by civil legislation... it is necessary to optimize intersectoral relations [10].

«Especially a large number of questions and practical problems arise while dividing the property of the spouses, when they own enterprises, business assets, securities, shares in the capital. There are many difficulties in alienating the shares owned by the spouses in a limited liability company» [11]. 
In recent years, the scientific community and at the legislative level have increasingly raised questions about the reform of legislation in the field of property relations, including those arising from the income of spouses from business activities acquired in marriage, as well as in connection with obligations to third parties. This is due to the fact that disputes about the division of property and business of spouses are very common in the courts. It seems that the issues of division of property in the event of divorce of spouses who conducted a joint business, have features related to the personal trust relationship between them. The use of various objects belonging to family members in the business projects of the spouses, the organization of family entrepreneurship is becoming more and more frequent, so the issues of determining the rights of former spouses to the objects of property rights related to the family business are very relevant.

The division of the spouses' business may also concern the interests of the children. In this regard, it is necessary to agree with the point of view expressed in the doctrine of S. $\mathrm{Yu}$. Chashkova that the Russian Federation, having created a system of measures aimed at protecting the property rights of children and other family members, does not fully use its existing mechanisms of legislative and other protection, which continues to lead to violations of the rights and interests of participants in family relations and indicates the lack of the expected effectiveness of such measures [12].

In comparison with the division of ordinary property of spouses, the business division has many features and ambiguous issues that cause many problems, both from the point of view of theory and from the point of view of practice. 3. The right of the spousesentrepreneurs to divide the common property of the spouses, which is enshrined in the family legislation, must be implemented taking into account the norms of the applicable specialized legislation: civil, corporate, entrepreneurial, etc. [13] In accordance with the draft law "On Amendments to the Federal Law" On the Development of Small and Medium-sized Enterprises in the Russian Federation "in terms of fixing the concept of "family enterprise", it is proposed to understand a small or medium-sized enterprise that meets one of the following criteria: a) more than half of the shares in the authorized capital of the company or more than half of the voting shares belong to one family, one of the members of which holds the position of the sole executive body or chairman of the board of directors or is charged with the responsibility of conducting the business of the business partnership; б)more than half of the members of a production or consumer cooperative or a peasant (farmer) farm are members of the same family; в) more than half of the employees of an individual entrepreneur are members of his family.

According to foreign scientists, understanding the economic and legal phenomenon of family business " allows us to structure the study of the resources that add value in family firms into four clearly distinguishable groups - organizational culture, reputation, human capital and networks, and also allows us to study the interaction of these intangible resources. We use this relationship to propose a future research program that aims to create a competitive advantage by combining and recombining these resources.» [14]. It seems appropriate to consolidate the concept of social entrepreneurship and family enterprise at the federal level in Russia, which will create legal, economic, marketing and technological conditions for strengthening the economic foundations, the development of the family as a social institution in our country.

\section{Conclusion}

1. As rightly noted by Professor V. P. Mozolin, there are reference norms in law that are equally applicable to all branches of law [15]. This approach is applicable to the implementation of the concept of synergy of family business and social entrepreneurship to solve the problems of the development of law, economics and technological processes. In 
the modern world, a legal entity is a legal form of participation of a group of persons in business activities and investment of capital in the economic sphere. In the context of universal global globalization, the actions of most states, and Russia is no exception, are aimed at creating a cross-border economic space in which the main economic entity is big business, not the state. Currently, there is a global trend that takes place in the Russian Federation - the socialization of economic processes, business activities and legislative regulation.

2. At present, during a difficult crisis situation in the economy and social conditions, a pandemic and the spread of coronavirus (COVID-19), social entrepreneurship and family business, it seems, could have a healing effect on the economic and social situation in Russian society. It is known that social entrepreneurship is a certain direction of development of the state social and economic policy, fixed at the legislative level.

3. The proposed amendments to Federal Law No. 209-FZ of July 24, 2007 "On the development of small and medium-sized businesses in the Russian Federation" are aimed at legislating the ability of citizens to carry out business activities in the form of a family enterprise, as well as determining the forms of possible state economic support for such enterprises. The implementation of the concept of a family enterprise can become an effective anti-crisis legal tool for solving socio-economic, technological, legal and demographic problems of the Russian population, society and the state. It seems reasonable for the Russian legislator to focus on the European law - making experience and, first of all, on the Italian one, where social entrepreneurship is legalized [16]. The Italian social cooperative used in practice is recommended as a model of social enterprise to the EU countries as an effective tool for solving various social problems [17].

4. While resolving issues about the division of the business of the spouses, the courts traditionally proceed from the fact that a variety of corporate assets, property of entrepreneurial purpose, obligations arising from the business activities of the spouses are considered not as a single complex - the business of the spouses - but as independent, unrelated objects subject to division. It seems that the property of this kind should be considered as a single total amount of property that is not subject to fragmentation into its component parts. Only this approach will allow the business to distance itself from the family-legal disputes of the spouses and to stabilize it, because otherwise, there is a high probability that the business of the spouses will not survive such a division of property.

\section{References}

1. L.B. Maksimovich, Problems of legal regulation of family entrepreneurship in Russia. Semeinyi biznes v pravovom prostranstve Rossii. Monografiya [Family business in the legal framework of Russia: monography], pp. 82-88 (Prospekt, Moscow, 2020). https://doi.org/10.31085/9785392299539-2020-624

2. A.A. Vlasov, A.N. Levushkin, T.E. Rakhmatullin, L.E. Rakhmatullina. Journal: “Opcion”. 19, 721-736 (2019)

3. On a relative: why do you need a family business? (interview with S.Katyrin) // URL.: https://tpprf.ru/ru/interaction/experts/comments/347045/

4. Ya.S. Grishina, Conceptual model of Legal support for Russian Social Entrepreneurship: Dis. ... Dr. yurid. sciences', 505, (2019)

5. A.N. Levushkin, A.V. Golysheva. Intersectoral approach to the legal regulation of corporate conflicts in modern Russia: theory and practice of application. In E3S Web of Conferences. 210, 9 (2020) https://doi.org/10.1051/e3sconf/202021013019

6. A.N. Levushkin, Journal Civil Law, 2, 6 - 10. (2019)

7. Yu. G. Leskova, Journal Civil Law, 6, 40. (2019)

8. A.V. Barkov, Ya. S. Grishina, Journal Civil Law, 2, 3 - 5. (2019) 
9. J.A. Davis, R. \& Tagiuri, Bivalent Attributes of the Family Firm. Family Business Review, 9, 200. (1996)

10. Yu.G. Leskova, Journal Inheritance law, 1, 11-13. (2017)

11. A.N. Levushkin, Journal Laws of Russia: Experience, Analysis, Practice. 4, 25 (2018)

12. S.Yu. Chashkova, Journal Family and housing law, 3, 29. (2020)

13. A.N. Levushkin, Journal Family and housing law, 2, (2021)

14. J. Huybrechts, W. Voordeckers, N. Lybaert, S. Vandemaele, The distinctiveness of family-firm intangibles: A review and suggestions for future research. Cambridge University Press and Australian and New Zealand Academy of Management. 17, 2, 268-287. (2011)

15. V.P. Mozolin, Journal of Russian Law, 1, 26 - 31. (2010)

16. Discipline of social cooperatives, Italian legislation portal «NORMATTIVA». (2020) URL: http://www.normattiva.it/atto/caricaDettaglioAtto? atto.dataPubblicazioneGazzetta=1991-1203\&atto.codiceRedazionale $=091 \mathrm{G} 0410$ \& currentPage $=1$

17. Communication from the commission to the european parliament, the council, the european economic and social committee and the committee of the regions entrepreneurship (2020). Action plan. URL: http:/eurlex.europa.eu/LexUriServ/LexUriServ.do?uri=COM:2012:0795:FIN:en:PDF 